\title{
Acute and subchronic antinociceptive effects of nociceptin/orphanin FQ receptor agonists infused by intrathecal route in rats
}

\author{
Laura Micheli $^{\mathrm{a}}$, Lorenzo Di Cesare Mannelli ${ }^{\mathrm{a}, *}$, Remo Guerrini ${ }^{\mathrm{b}}$, Claudio Trapella ${ }^{\mathrm{b}}$, \\ Matteo Zanardelli ${ }^{\mathrm{a}}$, Roberto Ciccocioppo ${ }^{\mathrm{d}}$, Anna Rizzi ${ }^{\mathrm{c}}$, Carla Ghelardini ${ }^{\mathrm{a}}$, Girolamo Calò ${ }^{\mathrm{c}}$ \\ a Department of Neuroscience, Psychology, Drug Research and Child Health - Neurofarba - Pharmacology and Toxicology Section, University of Florence, \\ Florence, Italy \\ ${ }^{\mathrm{b}}$ Department of Chemical and Pharmaceutical Sciences and LTTA, University of Ferrara, Ferrara, Italy \\ ${ }^{\mathrm{c}}$ Department of Medical Sciences, Section of Pharmacology and National Institute of Neuroscience, University of Ferrara, Italy \\ ${ }^{\mathrm{d}}$ School of Pharmacy, Pharmacology Unit, University of Camerino, Camerino, Italy
}

\section{A R T I C L E I N F O}

\section{Article history:}

Received 3 September 2014

Received in revised form

6 February 2015

Accepted 11 February 2015

Available online 19 February 2015

\section{Keywords:}

Morphine

Nociceptin/orphanin FQ

NOP receptor agonists

Spinal analgesia

Tolerance

\begin{abstract}
A B S T R A C T
Severe pain occurs in the context of many diseases and conditions and is a leading cause of disability. Nociceptin/orphanin FQ (N/OFQ) is the endogenous ligand of the N/OFQ peptide (NOP) receptor. This peptidergic system controls pain transmission and in particular spinally administered N/OFQ has robust antinociceptive properties.

The aim of this study was to investigate the spinal antinociceptive properties of NOP peptide agonists after acute and subchronic treatment in rats. Doses unable to alter motor coordination were selected. UFP-112 (full NOP agonist) and UFP-113 (partial NOP agonist) were administered intrathecally (i.t.) by spinal catheterization. Acute injection of UFP-112 induced antinociceptive response at lower dosages (0.03-1 nmol i.t.) compared to morphine and similar to N/OFQ. UFP-113 was effective in a $0.001-1 \mathrm{nmol}$ i.t. dose range. The antinociceptive effects of NOP ligands were no longer evident in rats knockout for the NOP gene, while those of morphine were maintained. The continuous spinal infusion (by osmotic pumps) of $0.1 \mathrm{nmol} / \mathrm{h}$ UFP-112 and UFP-113 showed antinociceptive action comparable to $1-3 \mathrm{nmol} / \mathrm{h}$ morphine or $\mathrm{N} / \mathrm{OFQ}$. The antinociceptive effect of morphine progressively decreased and was no longer significant after 6 days of treatment. Similar results were obtained with N/OFQ, UFP-112, and UFP-113. The acute i.t. injection of morphine in animals tolerant to N/OFQ and UFP-112 evoked analgesic effects. Neither morphine nor N/OFQ induced antinociceptive effects in morphine- and UFP-113-tolerant rats. In conclusion this study highlights the analgesic efficacy and potency of UFP-112 and UFP-113 underlining the relevance of NOP system in analgesia.
\end{abstract}

(c) 2015 Elsevier B.V. All rights reserved.

\section{Introduction}

Pain represents a widespread public health issue (Goldberg and McGee, 2011) with several effects on physical, emotional and cognitive functions. In particular, severe pain is defined as pain that persists beyond normal tissue healing time, or more than 3-6 months (Verhaak et al., 1998). Its time course is unpredictable and patients are often difficult to treat (Rowbotham, 1995).

Opioids are the most potent analgesic drugs commonly employed in order to relief moderate and severe pain (Dahan et al., 2013). Their effects are mediated by the mu, delta and kappa opioid peptide receptors (MOP, DOP and KOP, respectively) (Toll et al., 2014; Reisine

\footnotetext{
* Correspondence to: Neurofarba - Pharmacology and Toxicology Section, University of Florence, Viale Pieraccini 6, 50139, Florence, Italy. Tel.: +39055 4271316; fax: + 390554271280 .

E-mail address: lorenzo.mannelli@unifi.it (L. Di Cesare Mannelli).
}

and Pasternak, 1996; Waldhoer et al., 2004). Morphine, the gold standard for relieving pain, binds to all opioid receptors (Kieffer, 1999; Kieffer and Gavériaux-Ruff, 2002; Pasternak, 1993; Reisine and Bell, 1993) although it displays moderate selectivity for the MOP receptor (Zadina et al., 1994). Morphine is generally administered orally, transdermally, subcutaneously or intravenously (Osborne et al., 1990; Wojciech, 2011) although in the presence of severe pain it may be infused directly in the neuraxis by intrathecal (i.t.) route (Brogan and Winter, 2011; Vissers et al., 2011). The i.t. administration of centrally acting agents bypasses the blood brain barrier resulting in much higher cerebrospinal fluid concentrations while using reduced amounts of medication to achieve equieffective doses (Hayek et al., 2011). The efficacy and safety of this administration route were demonstrated in a number of studies, supporting its importance for chronic pain states (Coombs et al., 1984; Duarte et al., 2012; Follett et al., 1992; Krames et al., 1985, Krames and Lanning, 1993; Onofrio and Yaksh, 1990). 
Nonetheless, other pharmacological approaches are necessarily given the complexity of pain mechanisms and the evidence that chronic pain still represent an unmet medical need. Nociceptin/ orphanin FQ (N/OFQ) acts through the N/OFQ peptide receptor (NOP) which shares high structural homology with classical opioid targets (Meunier et al., 1995; Reinscheid et al., 1995). Despite high structural homology of the receptor and the peptide, and similar transductional mechanisms the N/OFQ - NOP receptor system is pharmacologically distinct from classical opioid systems (Lambert, 2008). N/OFQ has been shown to cause hyperalgesia, allodynia or analgesia depending on the dose and the route of administration. In most of the studies, N/OFQ supraspinal administration elicits pronociceptive effects in rodents and is able to counteract the antinociceptive effects of opioids (Zeilhofer and Calò, 2003). On the contrary N/OFQ administered i.t. induces antinociceptive effects (Zeilhofer and Calò, 2003).

The spinal antinociceptive effects of N/OFQ and NOP receptor agonists have been confirmed in a series of studies in non human primate (Ko et al., 2006; Ko and Naughton, 2009; Hu et al., 2010). Intrathecal administration of NOP agonists may represent a new approach to severe pain treatment. The aim of this study was to investigate in rats the acute and subchronic spinal effects of N/OFQ and NOP receptor agonists (UFP-112 and UFP-113) on pain transmission in comparison with the gold standard morphine.

\section{Materials and methods}

\subsection{Animals}

Male Sprague-Dawley and Wistar rats were supplied by Harlan (Varese, Italy). Male NOP $(-/-)$ rats supplied by GenOway (Lyon, France) were generated in a Brown Norway background and subsequently backcrossed on a Wistar background for eight generations as previously described in detail (Homberg et al., 2009). For knockout studies Wistar rats were used as controls and indicated as $\mathrm{NOP}(+/+)$. Animals, weighing approximately $280-300 \mathrm{~g}$ at the beginning of the experimental procedure were housed in single cage (size $26 \times$ $41 \mathrm{~cm}^{2}$ ). Animals were fed with standard laboratory diet and tap water ad libitum, and kept at $23 \pm 1{ }^{\circ} \mathrm{C}$ with a $12 \mathrm{~h}$ light/dark cycle, light at 7 a.m. All animal manipulations were carried out according to the European Community guidelines for animal care (DL 116/92), application of the European Communities Council Directive of 24 November 1986 (86/609/EEC). The ethical policy of the University of Florence complies with the Guide for the Care and Use of Laboratory Animals of the US National Institutes of Health (NIH Publication No. 85-23, revised 1996; University of Florence assurance number: A527801). Formal approval to conduct the experiments described was obtained from the Animal Subjects Review Board of the University of Florence and from the Italian Ministry of Health (No 54/2014-B). Experiments involving animals have been reported according to ARRIVE guidelines (Kilkenny et al., 2010). All efforts were made to minimize animal suffering and to reduce the number of animals used.

\subsection{Intrathecal catheterization}

Rats were anesthetized with $2 \%$ isoflurane and the intrathecal catheter was surgically implanted according to (Yaksh and Rudy, 1976). Rats were shaved on the back of the neck and placed in the stereotaxic frame with the head securely held between ear bars. The skin over the nap of the neck was cleaned with ethyl alcohol and incised for $1 \mathrm{~cm}$. The muscle on either side of the external occipital crest was detached and retracted to expose about $3-4 \mathrm{~mm}^{2}$ of the atlanto-occipital membrane. The membrane was incised by a needle, which led to the escape of cerebrospinal fluid. The caudal edge of the cut was lifted and about $7.0 \mathrm{~cm}$ of $28 \mathrm{G}$ polyurethane catheter $(0.36 \mathrm{~mm}$ outer diameter; $0.18 \mathrm{~mm}$ inner diameter; Alzet, USA) was gently inserted into the intrathecal space in the midline, dorsal to the spinal cord until the lumbar enlargement. The exit end of the catheter was connected to $4.0 \mathrm{~cm}$ polyurethane ( $0.84 \mathrm{~mm}$ outer diameter; $0.36 \mathrm{~mm}$ inner diameter) and was taken out through the skin, flushed with saline solution, sealed and securely fixed on the back of the head with a silk suture. For the chronic treatments osmotic pumps (Alzet, USA) were used. Pumps were attached with the exit end of the catheter and subcutaneously fixed on the back of the head. The incision site in the skin was sutured with polyamide suture and animals were allowed to recover for $24 \mathrm{~h}$ before the study began.

All animals used during behavioral tests did not shown motor impairment induced by surgical operation for the catheter implantation. The evaluation of potential motor dysfunctions were investigated using Rota rod test. The animals displaying motor disabilities (approximately 10\%) were excluded from the behavioral measurements.

\subsection{Drug treatments}

Morphine hydrochloride was from S.A.L.A.R.S., Como, Italy. N/OFQ, UFP-112 ([(pF)Phe $\left.\left.{ }^{4} \mathrm{Aib}^{7} \mathrm{Arg}^{14} \mathrm{Lys}^{15}\right] \mathrm{N} / \mathrm{OFQ}-\mathrm{NH}_{2}\right)$, and UFP$113\left(\left[\mathrm{Phe}^{1} \Psi\left(\mathrm{CH}_{2}-\mathrm{NH}\right) \mathrm{Gly}^{2}(\mathrm{pF}) \mathrm{Phe}^{4} \quad \mathrm{Aib}^{7} \mathrm{Arg}^{14} \mathrm{Lys}^{15}\right] \mathrm{N} / \mathrm{OFQ}-\mathrm{NH}_{2}\right)$ were synthesized and purified as previously described in detail (Arduin et al., 2007; Guerrini et al., 1997). All compounds were dissolved in sterile saline solution. Acute measures were performed after the i.t. infusion of 0.1-3 nmol morphine, 0.01-3 nmol N/OFQ, $0.03-0.3 \mathrm{nmol}$ UFP-112 and 0.001-1 nmol UFP-113. All
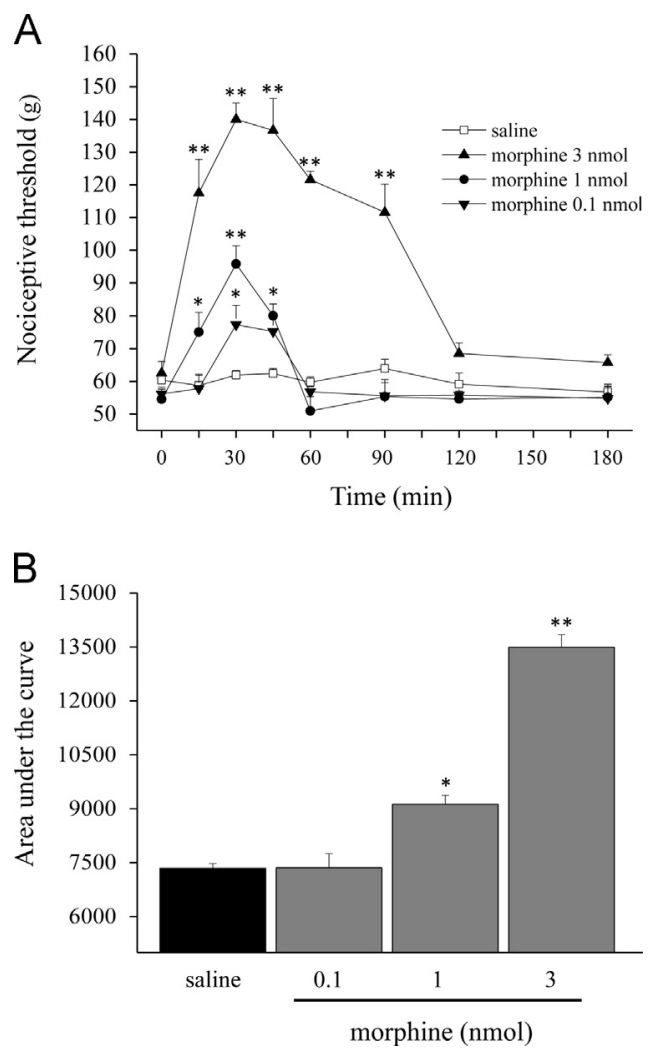

Fig. 1. A) Effect induced by intrathecal administration of morphine (dissolved in sterile saline) at doses from 0.1 to $3 \mathrm{nmol}$ i.t. Analgesic effect was evaluated by Pawpressure test performing from 15 to 180 min after acute injection. B) The Area Under Curve (AUC) represents the antinociceptive effect induced by acute intrathecal administration of morphine $(0.1-3 \mathrm{nmol})$ between 0 and $120 \mathrm{~min}$. Each value represent the mean of 6 rats performed in 2 different experimental set. Data are shown as mean \pm S.E.M.; ${ }^{*} P<0.05$ and ${ }^{* *} P<0.01$ in comparison to saline treated animals. 
Table 1

Evaluation of motor coordination after acute intrathecal administration of morphine, N/OFQ, UFP-112 and UFP-113.

\begin{tabular}{|c|c|c|c|c|c|c|c|}
\hline & \multicolumn{7}{|c|}{ Number of falls } \\
\hline & Pretest & $15 \mathrm{~min}$ & $30 \mathrm{~min}$ & $45 \mathrm{~min}$ & $60 \mathrm{~min}$ & $90 \mathrm{~min}$ & $120 \mathrm{~min}$ \\
\hline Saline & $1.0 \pm 0.5$ & $0.0 \pm 0.0$ & $1.0 \pm 0.2$ & $0.0 \pm 0.4$ & $0.0 \pm 0.0$ & $0.0 \pm 0.0$ & $0.0 \pm 0.0$ \\
\hline Morphine $3 \mathrm{nmol}$ & $0.5 \pm 0.5$ & $0.0 \pm 0.0$ & $0.0 \pm 0.0$ & $0.3 \pm 0.2$ & $0.0 \pm 0.0$ & $0.0 \pm 0.0$ & $0.0 \pm 0.0$ \\
\hline N/OFQ 3 nmol & $1.0 \pm 0.2$ & $0.0 \pm 0.0$ & $0.5 \pm 0.5$ & $0.3 \pm 0.0$ & $0.0 \pm 0.0$ & $1.0 \pm 0.0$ & $0.0 \pm 0.0$ \\
\hline UFP-112 $0.3 \mathrm{nmol}$ & $1.0 \pm 0.5$ & $1.0 \pm 0.6$ & $0.0 \pm 0.0$ & $0.5 \pm 0.5$ & $0.0 \pm 0.0$ & $0.0 \pm 0.0$ & $0.5 \pm 0.3$ \\
\hline UFP-113 1 nmol & $0.0 \pm 0.0$ & $0.0 \pm 0.0$ & $0.0 \pm 0.0$ & $0.0 \pm 0.0$ & $0.0 \pm 0.0$ & $0.0 \pm 0.0$ & $0.0 \pm 0.0$ \\
\hline
\end{tabular}

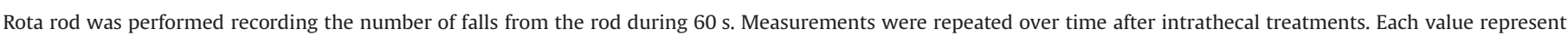
the mean of 6 rats performed in 2 different experimental set. Data are shown as mean \pm s.e.m.
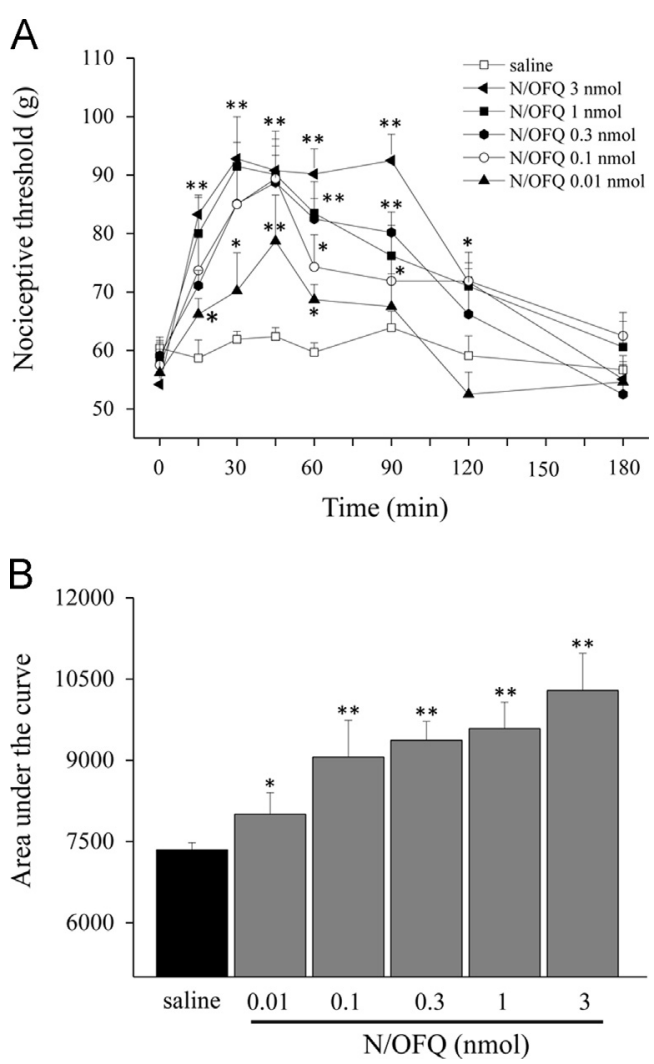

Fig. 2. A) Effect induced by intrathecal administration of N/OFQ (dissolved in sterile saline) at doses from 0.01 to $3 \mathrm{nmol}$ i.t. Analgesic effect was evaluated by Paw-pressure test performing from 15 to 180 min after acute injection. B) The Area Under Curve (AUC) represents the antinociceptive effect induced by acute intrathecal administration of N/OFQ (0.01-3 nmol) between 0 and 120 min. Each value represent the mean of 6 rats performed in 2 different experimental set. Data are shown as mean \pm S.E.M.; ${ }^{*} P<0.05$ and ${ }^{* *} P<0.01$ in comparison to saline treated animals.

compounds were infused in a final volume of $10 \mu \mathrm{l}$. Behavioral tests were carried out after 15, 30, 45, 60, 90, 120 and $180 \mathrm{~min}$.

For subchronic treatments, compound concentrations were adjusted to release 1 and $3 \mathrm{nmol} / \mathrm{h}$ morphine or $\mathrm{N} / \mathrm{OFQ}$ and $0.1 \mathrm{nmol} / \mathrm{h}$ UFP-112 or UFP-113, from a mini-osmotic pump ALZET 1002 (USA) with a flow rate $0.25 \mu \mathrm{L} / \mathrm{h}$ for 14 days. Final solutions were filtered by a $0.22 \mu \mathrm{m}$ pore size Hydrophilic PVDF membrane (Millipore, Italy). Mini-pump were attached to the described polyurethane catheters and filled with compounds or vehicle solutions, respectively. All mini-osmotic pumps were incubated in sterile saline solution overnight at $37^{\circ} \mathrm{C}$.

\subsection{Paw pressure test}

The nociceptive threshold in the rat was determined with an analgesimeter (Ugo Basile, Varese, Italy), according to the method
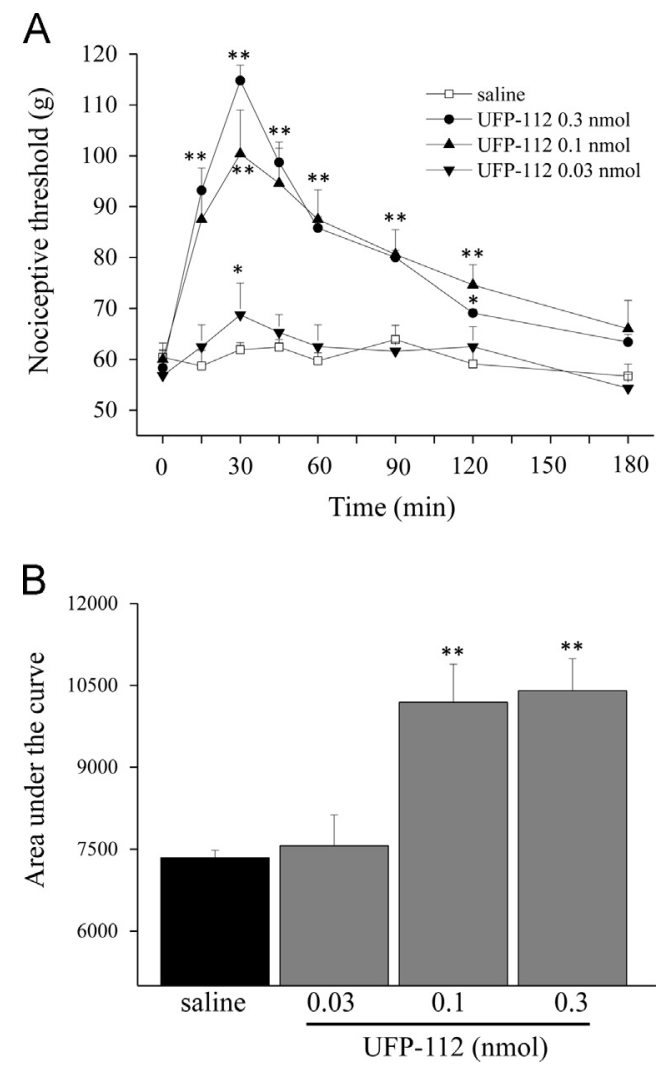

Fig. 3. A) Effect induced by intrathecal administration of UFP-112 (dissolved in sterile saline) at doses from 0.03 to $0.3 \mathrm{nmol}$ i.t. Analgesic effect was evaluated by Paw-pressure test performing from 15 to 180 min after acute injection. B) The Area Under Curve (AUC) represents the antinociceptive effect induced by acute intrathecal administration of UFP-112 (0.03-0.3 nmol) between 0 and $120 \mathrm{~min}$. Each value represent the mean of 6 rats performed in 2 different experimental set. Data are shown as mean \pm S.E.M.; ${ }^{*} P<0.05$ and ${ }^{* *} P<0.01$ in comparison to saline treated animals.

described by (Leighton et al., 1988). Briefly, a constantly increasing pressure was applied to a small area of the dorsal surface of the paw using a blunt conical probe by a mechanical device. Mechanical pressure was increased until vocalization or a withdrawal reflex occurred while rats were lightly restrained. Vocalization or withdrawal reflex thresholds were expressed in grams; a cut off pressure of $200 \mathrm{~g}$ was used to avoid tissue damage. All experiments were performed by a researcher blind to drug treatment.

\subsection{Rota-rod test}

Rota-rod apparatus (Ugo Basile, Varese, Italy) consisted of a base platform and a rotating rod with a diameter of $6 \mathrm{~cm}$ and a nonslippery surface. The rod was placed at a height of $25 \mathrm{~cm}$ from the base. The rod, $36 \mathrm{~cm}$ in length, was divided into 4 equal sections 
by 5 disks. Thus, up to 4 rats were tested simultaneously on the apparatus, with a rod-rotating speed of $10 \mathrm{rpm}$. The integrity of motor coordination was assessed on the basis of the number of falls from the rod in $60 \mathrm{~s}$ measured after 15, 30, 45, 60, 90 and 120 min after treatment for acute protocol. For subchronic treatments measurements were performed daily for 120 s. A cut off of 6 falls was used.

\subsection{Statistic analysis}

Behavioral measurements were performed on 6 rats for each treatment carried out in 2 different experimental sets. Results were expressed as means \pm S.E.M. and the analysis of variance was performed by one way ANOVA. A Bonferroni's significant difference procedure was used as post-hoc comparison. $P$ values of less than 0.05 or 0.01 were considered significant. Data were analyzed using the "Origin 9" software. Behavioral results of $\mathrm{NOP}(+/+)$ vs $\operatorname{NOP}(-/-)$ were analyzed by two way ANOVA followed by a Tukey's post-hoc test ("GraphPad Prism 6" software). The area under the curve (AUC) of the antinociceptive effects was calculated using the "Origin 9" software, evaluating the data from 0-120 min.

\section{Results}

\subsection{Acute antinociceptive effects}

The analgesic effects of acute i.t. injections of morphine and NOP agonists were evaluated in the rat paw pressure test. Animals injected with saline displayed a nociceptive threshold around $60 \mathrm{~g}$ that was stable over the time course of the experiments. Increasing doses of i.t. morphine $(0.1-3 \mathrm{nmol})$ evoked a robust antinociceptive effect in a dose-dependent manner (Fig. 1, panel A). The peak effect was measured after $30 \mathrm{~min}$ from injection for all doses. The maximal effect corresponding to $140.0 \pm 5.0 \mathrm{~g}$ was obtained in response to $3 \mathrm{nmol}$ morphine and the antinociceptive action of this dose was significant until 90 min and vanished 120 min after administration. The dose response curve to i.t. morphine expressed as area under the curve is shown in the panel B of Fig. 1. In this dose range morphine did not modify animal performance in the rota-rod test (Table 1).

Likewise morphine, $0.01-3 \mathrm{nmol} \mathrm{N} / \mathrm{OFQ}$ was tested i.t. to evaluate its analgesic effect in the rat (Fig. 2, panel A). All N/OFQ doses evoked antinociceptive effects starting $15 \mathrm{~min}$ after administration and peaked at $30-45 \mathrm{~min}$ after injection. $3 \mathrm{mnol}$ i.t. N/OFQ showed the highest antinociceptive effect that lasted up to $120 \mathrm{~min}$. The dose response curve of i.t. N/OFQ expressed as area under the curve is shown in the panel B of Fig. 2. At all dose tested N/OFQ did not led to any motor impairment in the rat rotarod test (Table 1). However at higher doses (i.e. 10 nmol i.t.) N/OFQ caused a clear impairment of animal motor performance.

Fig. 3 panel A shows the antinociceptive effect of acute intrathecal administration of the NOP selective full agonist UFP-112 tested in a dose range from 0.03 to $0.3 \mathrm{nmol}$. The antinociceptive effect induced by this NOP agonist was dose-dependent. At $0.3 \mathrm{nmol}$ i.t. the compound evoked the maximal effect at $30 \mathrm{~min}$ after intrathecal injection, the weight tolerated on the posterior paw was of $114.8 \pm 3.0 \mathrm{~g}$ (in comparison to basal value $58.3 \pm 0.8 \mathrm{~g}$ ). The effect was significant until 120 min after administration. The dose response curve of i.t. UFP-112 expressed as area under the curve is shown in the panel B of Fig. 3. At higher doses ( 1 and $3 \mathrm{nmol}$ ), UFP-112 caused an impairment of motor coordination up to the paralysis of posterior paws $(10 \mathrm{nmol})$.

Acute effects of the NOP partial agonist UFP-113 were evaluated after the administration of doses ranging 0.001 and $1 \mathrm{nmol}$ i.t. (Fig. 4, panel A). Similar to UFP-112, the dose of $3 \mathrm{nmol}$ and $10 \mathrm{nmol}$ impeded the maintenance of balance on the rotating rod or paralyzed posterior paws, respectively. Lower doses of UFP-113 did not evoked motor side effects in the rat. The analgesic response to $1 \mathrm{nmol}$ i.t. of UFP-113 appeared $15 \mathrm{~min}$ after injection $(83.3 \pm 3.5 \mathrm{~g})$ with a maximum
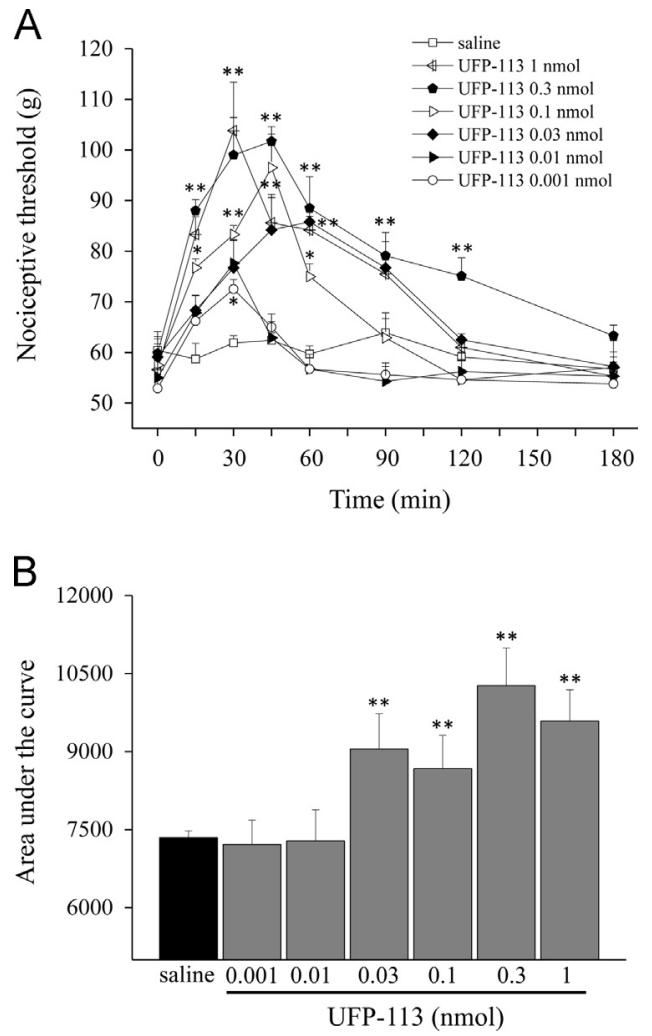

Fig. 4. A) Effect induced by intrathecal administration of UFP-113 (dissolved in sterile saline) at doses from 0.001 to $1 \mathrm{nmol}$ i.t. Analgesic effect was evaluated by Paw-pressure test performing from 15 to $180 \mathrm{~min}$ after acute injection. B) The Area Under Curve (AUC) represents the antinociceptive effect induced by acute intrathecal administration of UFP$113(0.001-1 \mathrm{nmol})$ between 0 and $120 \mathrm{~min}$. Each value represent the mean of 6 rats performed in 2 different experimental set. Data are shown as mean \pm S.E.M.; ${ }^{*} P<0.05$ and ${ }^{* *} \mathrm{P}<0.01$ in comparison to saline treated animals.

response around $30 \mathrm{~min}(103.8 \pm 9.6 \mathrm{~g})$. The effect progressively decreased over time, vanishing $120 \mathrm{~min}$ after administration $(55.3 \pm 4.8 \mathrm{~g})$. At doses between $0.03-0.3$ UFP-113 led to timedependent and dose-dependent antinociceptive effects. Analgesia started $15 \mathrm{~min}$ after injection and reached the maximum values between 30 and $45 \mathrm{~min}$. The dose of $0.3 \mathrm{nmol}$ i.t. induced the highest antinociceptive effect that was reached $45 \mathrm{~min}$ after compound administration $(101.7 \pm 2.6 \mathrm{~g})$. The dose response curve of i.t. UFP-113 expressed as area under the curve is shown in the panel B of Fig. 4. The spinal antinociceptive effects of these compounds were also assessed in $\operatorname{NOP}(-/-)$ rats. Results obtained with $3 \mathrm{nmol}$ morphine and N/OFQ 0.3 nmol UFP-112 and 1 nmol UFP-113 were summarized in Fig. 5. Pain threshold were similar in $\mathrm{NOP}(+/+)$ and $\operatorname{NOP}(-/-)$ rats. Morphine elicited a robust antinociceptive effect in both $\mathrm{NOP}(+/+)$ and $\mathrm{NOP}(-/-)$ animals (Fig. 5A); however the effect of the alkaloid was larger in $\mathrm{NOP}(+/+)$ rats The AUC were also calculated in Wistar $\mathrm{NOP}(+/+)$ and $\operatorname{NOP}(-/-)$ rats and two way ANOVA was performed. The AUC of $3 \mathrm{nmol}$ morphine antinociceptive effect in $\mathrm{NOP}(+/+)$ rats was statistically different in comparison to the AUC of $3 \mathrm{nmol}$ morphine in $\mathrm{NOP}(-/-)$ rats $(13640.62 \pm 178.12$ and $10182.56 \pm 49.07$, respectively; $P<0.001)$. In $\mathrm{NOP}(+/+)$ rats, N/OFQ UFP-112, and UFP-113 displayed antinociceptive effects similar to those obtained in SD animals while their effect completely disappeared in $\operatorname{NOP}(-/-)$ animals (Fig. 5 panel B, C, and D).

\subsection{Subchronic antinociceptive effects}

We used the same surgical procedure of spinal catheterization to analyze the analgesic profile of these compounds during a continuous i.t. infusion. To allow a constant delivery of substances 
A

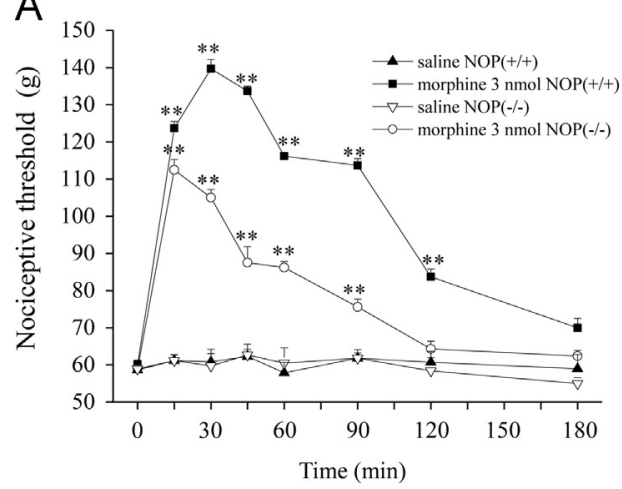

C

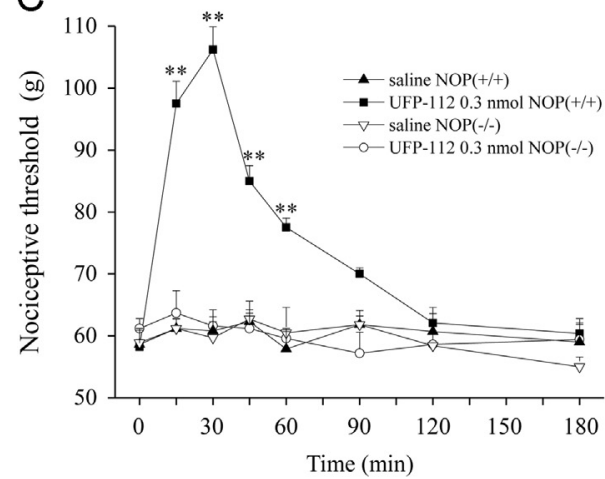

B

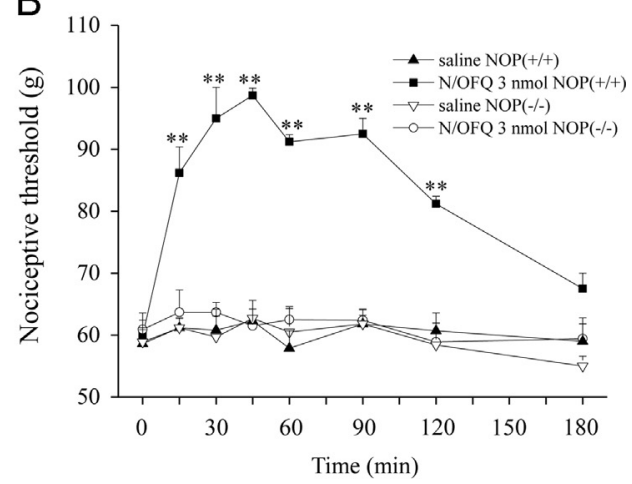

D

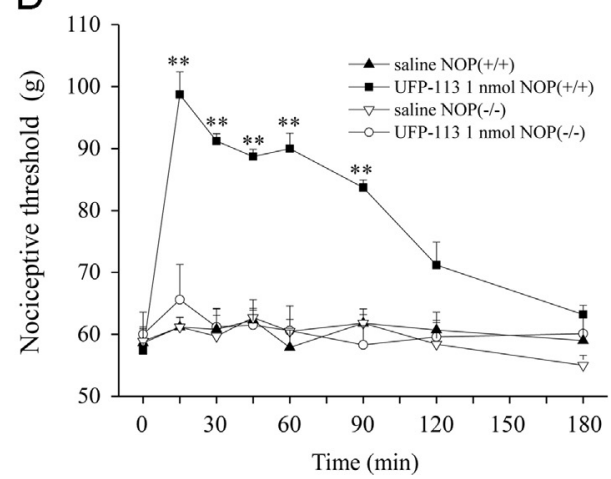

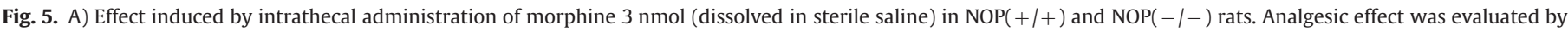

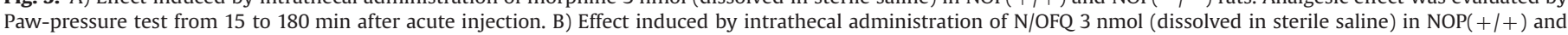

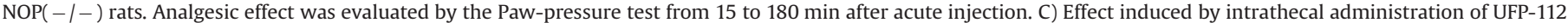

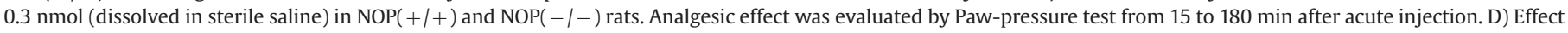

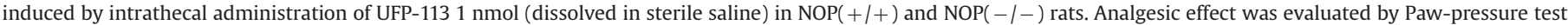

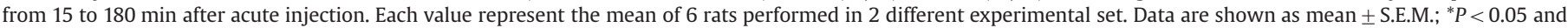
${ }^{* *} P<0.01$ in comparison to saline treated animals.

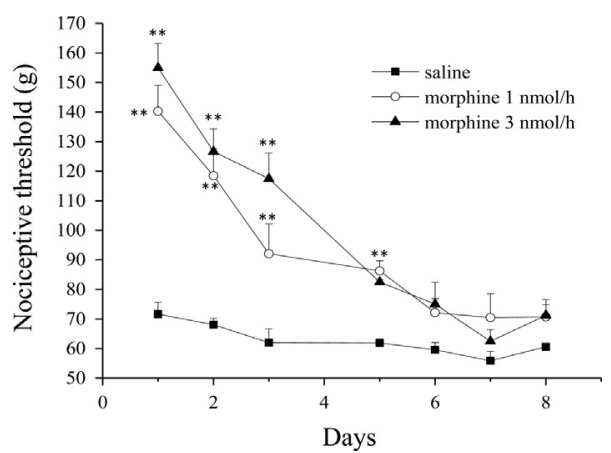

Fig. 6. Effect induced by continuous intrathecal infusion of morphine. The compound was dissolved in sterile saline and administered in two different groups of animals at doses of 1 and $3 \mathrm{nmol} / \mathrm{h}$ with osmotic pumps until day 8 . Analgesic effect was evaluated every day by Paw-pressure test during the entire duration of treatment, starting on the 1th day of infusion. Each value represents the mean of 6 rats performed in 2 different experimental set. Data are shown as mean \pm S.E.M. ${ }^{* *} P<0.01$ in comparison to control animals treated with saline.

over days, mini-osmotic pumps connected to the catheters were used. Pain threshold and motor coordination were evaluated every day by paw pressure and rota rod tests.

Morphine was continuously infused into two different groups of animals at the doses of 1 and $3 \mathrm{nmol} / \mathrm{h}$ (Fig. 6). Every day the analgesic effect was measured in comparison with rats treated with saline solution by the same route of administration. Animal treated with saline displayed stable pain threshold over the time course of the experiment ( 8 days). The first day of infusion the nociceptive threshold reached $118.5 \pm 9.0 \mathrm{~g}$ and $126.6 \pm 7.6 \mathrm{~g}$ for 1 and $3 \mathrm{nmol} /$

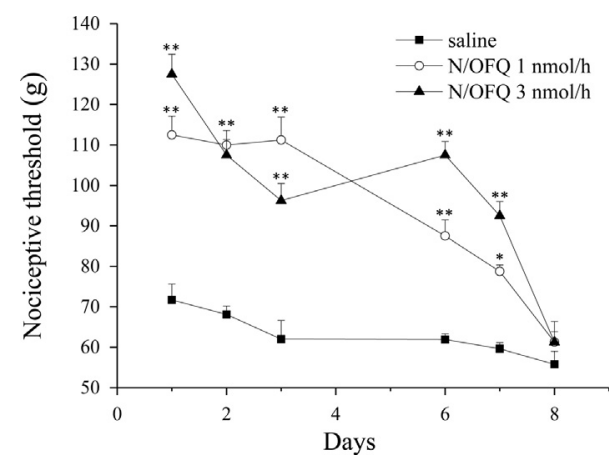

Fig. 7. Effect induced by continuous intrathecal infusion of N/OFQ. The compound was dissolved in sterile saline and administered in two different groups of animals at doses of 1 and $3 \mathrm{nmol} / \mathrm{h}$ with osmotic pumps until day 8. Analgesic effect was evaluated every day by Paw-pressure test during the entire duration of treatment, starting on the 1th day of infusion. Each value represent the mean of 6 rats performed in 2 different experimental set. Data are shown as mean \pm S.E.M.; ${ }^{*} P<0.05$ and ${ }^{* *} P<0.01$ in comparison to control animals treated with saline.

h-treatment group, respectively. Antinociceptive effect started to decrease from day 2 until day 5 of infusion when the values recorded were still statistically significant $(72.1 \pm 4.6 \mathrm{~g}$ for $1 \mathrm{nmol} /$ and $75.0 \pm 7.4 \mathrm{~g}$ for $3 \mathrm{nmol} / \mathrm{h}$ ). Starting from day 6 no differences were evident in pain threshold of animal treated with spinal morphine or saline (Fig. 6). Similar to morphine, N/OFQ was continuously infused spinally at doses of 1 and $3 \mathrm{nmol} / \mathrm{h}$. (Fig. 7). Both doses induced a robust antinociceptive effect that peaked the first day of infusion $(112.5 \pm 4.6 \mathrm{~g}$ for $1 \mathrm{nmol} / \mathrm{h}$ and $127.5 \pm 4.9 \mathrm{~g}$ for $3 \mathrm{nmol} / \mathrm{h}$ ), and then progressively decreased over the time course of 


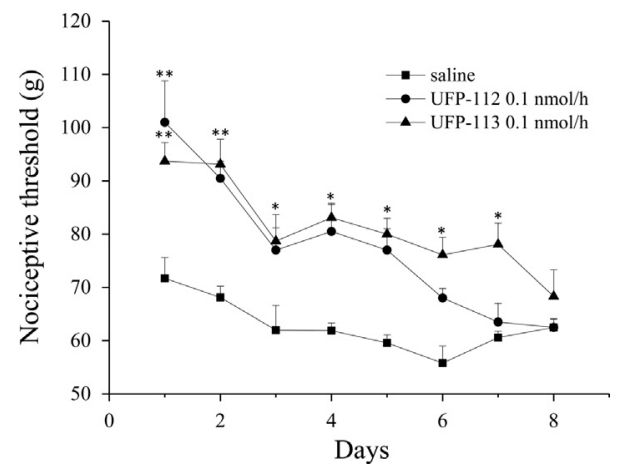

Fig. 8. Effect induced by continuous intrathecal infusion of UFP-112 and UFP-113. Compounds were dissolved in sterile saline and administered in two different groups of animals both at dose of $0.1 \mathrm{nmol} / \mathrm{h}$ with osmotic pumps until day 8 . Analgesic effect was evaluated every day by Paw-pressure test during the entire duration of treatment, starting on the 1th day of infusion. Each value represent the mean of 6 rats performed in 2 different experimental set. Data are shown as mean \pm S.E.M.; ${ }^{*} P<0.05$ and ${ }^{* *} P<0.01$ in comparison to control animals treated with saline.

the experiment. On day 8 no differences were evident in pain threshold of animal treated with spinal N/OFQ or saline (Fig. 7).

Fig. 8 displays the antinociceptive effect of UFP-112 and UFP-113, both given as continuous i.t. infusion at the dose of $0.1 \mathrm{nmol} / \mathrm{h}$. On day 1, UFP-112 increased pain threshold up to $101.0 \pm 7.8 \mathrm{~g}$ in comparison to pain threshold measured in saline-treated animals $(71.7 \pm 3.9)$. The antinociceptive effect of UFP-112 was statistically significant up to day 5. Animals continuously infused with UFP-113 showed a pain threshold of $93.7 \pm 3.5 \mathrm{~g}$ on the first day of treatment. The effect of UFP-113 was statistically significant up to day 7. During compound infusion, the motor coordination of the animals was evaluated every day by the rota rod test (Table 2). Motor coordination of morphine, N/OFQ UFP-112 and UFP-113 treated animals, evaluated as number of falls during $120 \mathrm{~s}$, did not show significant differences compared to saline-infused animals.

Finally at day 9 osmotic pumps were removed to evaluate the effect of acute treatment with $3 \mathrm{nmol}$ of N/OFQ and morphine in tolerant animals.

In spinal morphine tolerant animals the acute i.t. administration of $3 \mathrm{nmol}$ of morphine or N/OFQ did not modify pain threshold (Fig. 9A). The same experiments were performed in spinal N/OFQ tolerant rats (Fig. 9B). Acute intrathecal administration of morphine induced a clear antinociceptive effect 15 and 30 min after injection with a weight of $96.2 \pm 3.3$ and $92.7 \pm 4.6$ respectively. In these animals the spinal injection of N/OFQ was inactive. Similar results were obtained in spinal UFP-112 tolerant rats in which acute morphine produced statistically significant effects while N/OFQ was inactive (Fig. 9C). In animals tolerant to the spinal effects of UFP-113 both morphine and N/OFQ were inactive (Fig. 9D).

\section{Discussion}

In spite of opioid efficacy (Pasternak and Pan, 2013) an estimated $80 \%$ of persons worldwide do not receive adequate treatment to relieve pain (WHO, 2007). The unsuitableness of therapy is often related to legal restrictions on the availability of opioid analgesics (Weber et al., 2012), furthermore adverse effects limit the use of these drugs (Morgan, 1989). Along with increase in the prevalence of chronic pain, long-term therapies with opioids exacerbate toxicity and the development of analgesic tolerance (Williams et al., 2013) and dependence is a significant limit in their clinical applications (Koob and Bloom, 1988). Research efforts in the field of analgesics are focused on the discovery of new compounds as well as of new pharmaceutical forms and routes of administration. The i.t. route offers a safe and effective alternative when i.v. or oral opioids are only partially effective
(Grady and Raphael, 2008; Grider et al., 2011) e.g. for the management of chronic non-cancer pain (Biggs et al., 2011; De Lissovoy et al., 1997; Hassenbusch et al., 1997). Recent studies support the long-term effectiveness following 3 years of treatment (Duarte et al., 2012). Opioid administration into the intrathecal space achieves its effects at lower doses than by using the epidural route (Nordberg et al., 1984). The drug is highly localized, and its analgesic efficacy is maximized at lower doses (Bernards, 2006) reducing systemic narcotic exposure by a factor of 300 to 1 (Smith et al., 2005). Moreover, opioid dose escalation over time may be modest. These factors lead to a decrease in the appearance of opioid side effects (Duarte et al., 2012).

Aimed to reach an alternative and exploitable pharmacological target by spinal delivery, we compared the efficacy of morphine with that of NOP receptor agonists. Spinal morphine produced a dose dependent and robust antinociceptive effect in line with previous findings (Kosson et al., 2008). A similar antinociceptive action has been promoted by the spinal injection of N/OFQ accordingly to (Schroder et al., 2014; Zeilhofer and Calò, 2003;). Compared to morphine, N/OFQ displayed similar potency but reduced maximal effects. This is possibly due to the appearance of side effects for the high doses of peptide (flaccidity of the hindlimbs and consequent disruption of rota-rod performance). Similar findings were reported in mice (Nazzaro et al. 2007). Thus, in rodents the therapeutic index of N/OFQ as spinal analgesic is clearly lower than that of morphine. However different results were obtained in non human primates where the i.t. administration of $\mathrm{N} / \mathrm{OFQ}$ in a large range of doses produced robust antinociceptive effects without affecting motor behavior (Hu et al. 2010; Ko and Naughton, 2009). Importantly, the antinociceptive maximal effects of N/OFQ were similar to that of morphine. Moreover the action of N/OFQ was behaviorally selective; in fact the administration of analgesic doses of morphine promoted scratching responses in monkeys while N/OFQ did not. This evidence suggests the existence of relevant species differences regarding the therapeutic potential of NOP agonists as spinal analgesics (Schroder et al., 2014).

UFP-112 is a NOP receptor ligand designed by combining several chemical modifications in the same peptide sequence to increase NOP receptor affinity/potency and/or reduce susceptibility to enzymatic degradation (Rizzi et al., 2007). The NOP receptor full agonist pharmacological activity of UFP-112 has been confirmed in several in vitro and in vivo studies reviewed in Calo' et al. (2011). In the present study, UFP-112 elicited a dose-dependent antinociceptive response after acute i.t. administration in the rat showing similar efficacy and potency as N/OFQ. Similar although not superimposable results were previously obtained in mice (Rizzi et al., 2011) where UFP-112 was 100 fold more potent that N/OFQ and produced longer lasting effects. The spinal antinociceptive properties of UFP-112 were also confirmed in monkeys (Hu et al., 2010). Collectively this evidence demonstrated that UFP-112 mimicked the antinociceptive effects of $\mathrm{N} / \mathrm{OFQ}$ in the rat, mouse and monkeys showing similar or higher potency than the natural peptide.

The spinal antinociceptive action of the NOP partial agonist UFP113 (Arduin et al., 2007; Camarda et al., 2009) has been evaluated in the present research for the first time. Acute i.t. administration of UFP-113 increased pain threshold in a dose dependent manner and with high potency. Despite the NOP partial agonist activity measured in in vitro studies (Arduin et al., 2007) with this molecule, UFP-113 maximal antinociceptive effects were similar to those measured in response to spinal N/OFQ and UFP-112. This result is not completely unexpected. In fact, the NOP partial agonist [F/G]N/OFQ(1-13)- $\mathrm{NH}_{2}$ that shares with UFP-113 the chemical modification at the Phe ${ }^{1}-\mathrm{Gly}^{2}$ peptide bond that reduces efficacy (Calo' et al., 2000) displayed full agonist activity when given spinally in the rat tail flick test (Candeletti et al., 2000, Wang et al., 1999).

Doses higher than $0.3 \mathrm{nmol}$ for UFP-112 and $1 \mathrm{nmol}$ for UFP-113 induced disruption of motor coordination. This side effect is also evoked by N/OFQ at high doses (i.e. $10 \mathrm{nmol}$ ). This order of potency 
Table 2

Evaluation of motor coordination during continuous intrathecal infusion of morphine, N/OFQ, UFP-112 and UFP-113.

\begin{tabular}{|c|c|c|c|c|c|c|c|}
\hline & \multicolumn{7}{|c|}{ Number of falls } \\
\hline & Day 1 & Day 2 & Day 3 & Day 4 & Day 5 & Day 6 & Day 7 \\
\hline Saline & $1.1 \pm 0.5$ & $1.0 \pm 0.2$ & $1.1 \pm 0.3$ & $1.3 \pm 0.4$ & $1.0 \pm 0.1$ & $0.5 \pm 0.2$ & $0.7 \pm 0.3$ \\
\hline Morphine $3 \mathrm{nmol}$ & $1.5 \pm 0.2$ & $0.5 \pm 0.2$ & $0.5 \pm 0.2$ & $1.0 \pm 0.0$ & $0.5 \pm 0.3$ & $0.0 \pm 0.0$ & $0.0 \pm 0.0$ \\
\hline N/OFQ 3 nmol & $0.3 \pm 0.3$ & $1.3 \pm 0.8$ & $1.1 \pm 0.5$ & $0.3 \pm 0.0$ & $0.0 \pm 0.0$ & $1.0 \pm 0.0$ & $0.0 \pm 0.0$ \\
\hline UFP-112 0.1 nmol & $1.5 \pm 0.7$ & $1.2 \pm 1.3$ & $1.5 \pm 0.8$ & $1.2 \pm 0.8$ & $1.0 \pm 1.0$ & $1.0 \pm 0.3$ & $0.0 \pm 0.0$ \\
\hline UFP-113 0.1 nmol & $1.2 \pm 0.8$ & $1.4 \pm 0.5$ & $1.0 \pm 0.8$ & $1.0 \pm 0.4$ & $0.0 \pm 0.0$ & $0.5 \pm 0.5$ & $1.0 \pm 0.1$ \\
\hline
\end{tabular}

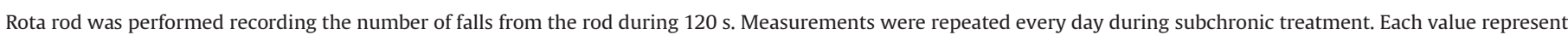
the mean of 6 rats performed in 2 different experimental sets. Data are shown as mean \pm s.e.m.
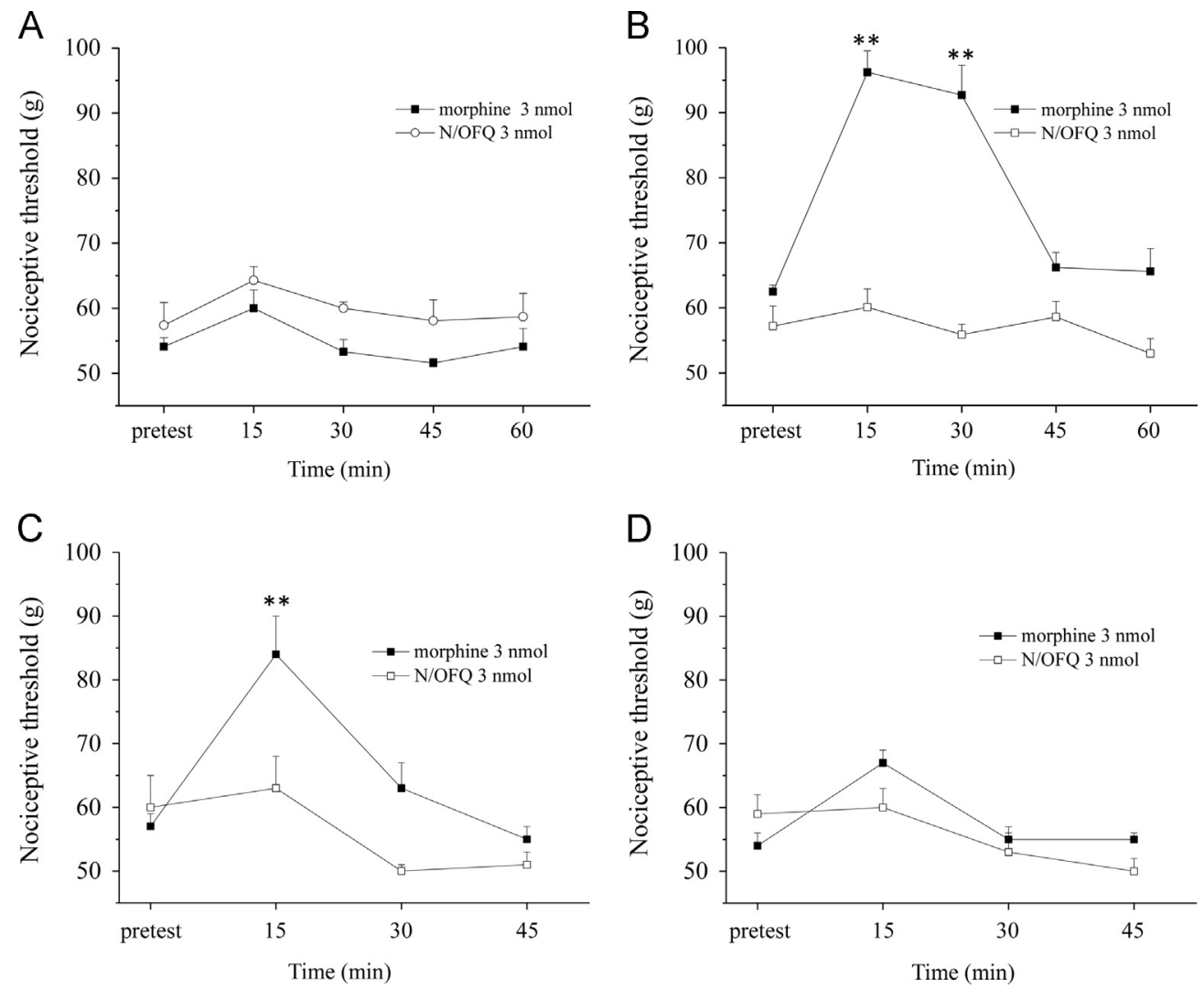

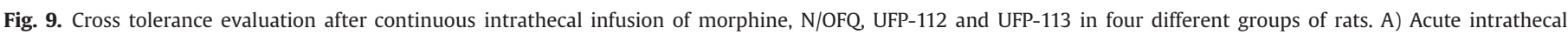

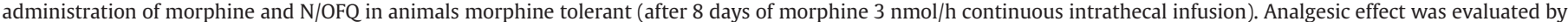

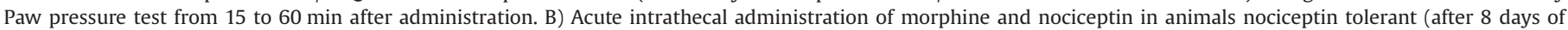

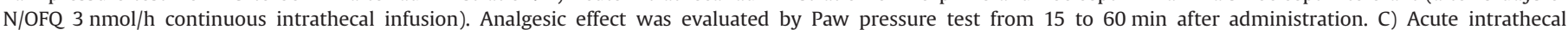

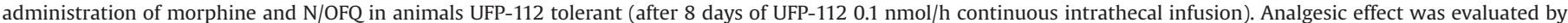

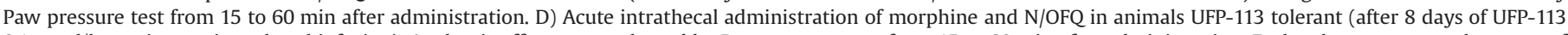

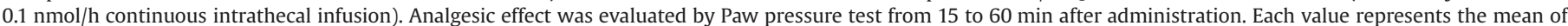
6 rats. Data are shown as mean \pm S.E.M.; ${ }^{* *} P<0.01$ in comparison to the pretest.

perfectly matches the rank order of potency of these peptides as NOP ligands (Arduin et al., 2007) thus suggesting that motor impairment derives from an overstimulation of spinal NOP receptors.

$\operatorname{NOP}(-/-)$ rats (Homberg et al., 2009) were used to investigate the involvement of the NOP receptor in the antinociceptive action of the compounds under study. $\mathrm{NOP}(+/+)$ and $\mathrm{NOP}(-/-)$ rats displayed similar pain threshold in the Paw pressure test. This is in line with studies performed in NOP knockout mice (Depner et al., 2003; Nishi et al., 1997) suggesting that the endogenous N/OFQ NOP receptor system does not tonically control nociceptive transmission (Zeilhofer and Calò, 2003). The spinal injection of morphine in $\operatorname{NOP}(-/-)$ rats produced a clear antinociceptive effect while N/OFQ UFP-112 and UFP-113 were completely inactive. These findings clearly demonstrated the exclusive involvement of the NOP receptor in the spinal antinociceptive action of these latter compounds. Interestingly the antinociceptive effect of morphine was reduced in $\mathrm{NOP}(-/-)$ compared to $\mathrm{NOP}(+/+)$ rats. This finding contrasts with that reported in mice where the analgesic effect of morphine was similar in $\mathrm{NOP}(+/+)$ and NOP $(-/-)$ animals (Mamiya et al., 2001; Ueda et al., 1997). This might suggest an involvement of N/OFQergic signaling in the antinociceptive action of spinal morphine in rats but not in mice.

Results obtained in acute dose response studies were used to select the appropriate doses of compounds to be assessed for their effects during continuous infusion. All compounds did not induce motor dysfunctions during infusion at the described dosages. Morphine induces significant analgesic effect that displayed progressive reduction over the time course of the experiment. After 6 days of 
continuous infusion rats become fully tolerant to the antinociceptive effect of the alkaloid according to previous studies (Huang et al., 2012; Jhamandas et al., 1998; Wen et al., 2005). Similar results, accordingly with (Hao et al., 1997; Jhamandas et al., 1998), were obtained in rats treated with N/OFQ that become fully tolerant to the action of the peptide after 8 days. Rats treated with continuous infusion of UFP-112 or UFP-113 also display a progressive reduction of their antinociceptive effects and become fully tolerant after 6 and 8 days respectively. The partial agonist profile of UFP-113 does not seem to be sufficient to significantly affect the development of tolerance.

In order to get information about cross tolerance between NOP and classical opioid receptors, at day 9 tolerant rats were acutely injected with $3 \mathrm{nmol}$ of $\mathrm{N} / \mathrm{OFQ}$ or morphine. In rats tolerant to N/OFQ or UFP-112, the injection of morphine elicited a significant antinociceptive effect; compared to naïve animals however morphine efficacy was reduced. These results are at least partially in line with what reported by (Hao et al., 1997) who demonstrated in the rat tail flick assay a complete lack of cross tolerance to morphine in N/OFQtolerant rats. The alkaloid was completely inactive in rats tolerant to UFP-113. This result suggests that classical opioid receptors might be involved into the antinociceptive action of this compound despite the high NOP selectivity of UFP-113 reported in receptor binding studies (Arduin et al., 2007) and confirmed by the present acute studies in $\operatorname{NOP}(-/-)$ rats. However we cannot completely exclude the involvement of classical opioid receptors in the subchronic action of UFP-113. In fact, some effects of the UFP-113 analog [F/G]N/OFQ(1-13)- $\mathrm{NH}_{2}$ are partially reversed by naloxone (Carpenter and Dickenson, 1998).

20Finally the i.t. injection of N/OFQ was inactive in morphine tolerant rats. This result is in line with the findings of Jhamandas et al. (1998) who demonstrated that the dose response curve to $\mathrm{N} / \mathrm{OFQ}$ is significantly shifted to the right in morphine-tolerant rats. However other studies demonstrated lack of tolerance to the antinociceptive effects of N/OFQ in morphine tolerant rats (Hao et al., 1997). Thus the appearance (or lack) of cross tolerance between the spinal antinociceptive effect of N/OFQ and classical opioids seems to strongly depend on experimental conditions in rodents.

\section{Conclusion}

Intrathecal administration of N/OFQ, the NOP full agonist UFP112 and the partial agonist UFP-113 produced a dose dependent antinociceptive effect with the following rank order of potency UFP-113 $>$ UFP-112 $\geq$ N/OFQ. The exclusive involvement of the NOP receptor in the antinociceptive action of these compounds has been confirmed by knockout studies. Compared to morphine, the spinal antinociceptive potential of NOP agonist is limited by the appearance of motor side effects. Chronic studies demonstrated a similar tolerance liability for morphine and NOP agonists. Cross tolerance studies suggest a higher impact for morphine continuous infusion on N/OFQ induced antinociception then vice versa. This study extended our knowledge on the potential of NOP agonists as spinal analgesics. Importantly this information can be in instrumental for the design of proof of concept studies in non human primates where the potential of NOP agonists as analgesics seems to be extremely promising (Lin and Ko, 2013). However firm conclusions on the therapeutic potential of NOP agonists as innovative spinal analgesics can be drawn only after performing clinical trials in which N/OFQ will be spinally administered in pain patients (Al Hashimi et al., 2012).

\section{Acknowledgments}

This research was funded by the Italian Ministry of Instruction, University and Research (FIRB grant to CT), the University of
Florence (FAR grant to CG), and the University of Ferrara (FAR grant to GC).

\section{References}

Al Hashimi, M., Calo, G., Guerrini, R., Thompson, J.P., Lambert, D.G., 2012 Nociceptin/orphanin FQ: protocol presentation of the first intrathecal use in humans. In: Proceedings of the Anaesthetic Research Society Meeting, Aberdeen, 21-22 June 2012.

Arduin, M., Spagnolo, B., Calò, G., Guerrini, R., Carrà, G., Fischetti, C., Trapella, C. Marzola, E., McDonald, J., Lambert, D.G., Regoli, D., Salvadori, S., 2007. Synthesis and biological activity of nociceptin/orphanin FQ analogues substituted in position 7 or 11 with Calpha, alpha-dialkylated amino acids. Bioorg. Med. Chem. 15, 4434-4443.

Bernards, C.M., 2006. Cerebrospinal fluid and spinal cord distribution of baclofen and bupivacaine during slow intrathecal infusion in pigs. Anesthesiology 105, 169-178.

Biggs, S.A., Duarte, R.V., Raphael, J.H., Ashford, R.L., 2011. Influence of a latent period in QALY analysis: pilot study of intrathecal drug delivery systems for chronic non-malignant pain. Br. J. Neurosurg. 25, 401-406.

Brogan, S.E., Winter, N.B., 2011. Patient-controlled intrathecal analgesia for the management of breakthrough cancer pain: a retrospective review and commentary. Pain Med. 12, 1758-1768.

Calo', G., Guerrini, R., Rizzi, A., Salvadori, S., Regoli, D., 2000. Pharmacology of nociceptin and its receptor: a novel therapeutic target. Br. J. Pharmacol. 129, 1261-1283.

Calo', G., Rizzi, A., Cifani, C., Micioni Di Bonaventura, M.V., Regoli, D., Massi, M. Salvadori, S., Lambert, D.G., Guerrini, R., 2011. UFP-112 a potent and long-lasting agonist selective for the Nociceptin/Orphanin FQ receptor. CNS Neurosci. Ther. 17, 178-198.

Camarda, V., Fischetti, C., Anzellotti, N., Molinari, P., Ambrosio, C., Kostenis, E., Regoli, D. Trapella, C., Guerrini, R. Severo, S., Calò, G., 2009. Pharmacological profile of NOP receptors coupled with calcium signaling via the chimeric protein G alpha qi5. Naunyn. Schmiedebergs Arch. Pharmacol. 379, 599-607.

Candeletti, S., Guerrini, R., Calò, G., Romualdi, P., Ferri, S., 2000. Supraspinal and spinal effects of [Phe1psi(CH2-NH)Gly2]-nociceptin(1-13)-NH2 on nociception in the rat. Life Sci. 66, 257-264.

Carpenter, K.J., Dickenson, A.H., 1998. Evidence that [Phe1 psi(CH2-NH)Gly2] nociceptin-(1-13)-NH2, a peripheral ORL-1 receptor antagonist, acts as an agonist in the rat spinal cord. Br. J. Pharmacol. 125, 949-951.

Coombs, D.W., Maurer, L.H., Saunders, R.L., Gaylor, M., 1984. Outcomes and complications of continuous intraspinal narcotic analgesia for cancer pain control. J. Clin. Oncol. 2, 1414-1420.

Dahan, A., Overdyk, F., Smith, T., Aarts, L., Niesters, M., 2013. Pharmacovigilance: a review of opioid-induced respiratory depression in chronic pain patients. Pain Physician 16, 85-94.

De Lissovoy, G., Brown, R.E., Halpern, M., Hassenbusch, S.J., Ross, E., 1997. Costeffectiveness of long-term intrathecal morphine therapy for pain associated with failed back surgery syndrome. Clin. Ther. 19, 96-112.

Depner, U.B., Reinscheid, R.K., Takeshima, H., Brune, K., Zeilhofer, H.U., 2003. Normal sensitivity to acute pain, but increased inflammatory hyperalgesia in mice lacking the nociceptin precursor polypeptide or the nociceptin receptor. Eur. J. Neurosci. 17, 2381-2387.

Duarte, R.V., Raphael, J.H., Haque, M.S., Southall, J.L., Ashford, R.L., 2012. A predictive model for intrathecal opioid dose escalation for chronic non-cancer pain. Pain Physician 15, 363-369.

Follett, K.A., Hitchon, P.W., Piper, J., Kumar, V., Clamon, G., Jones, M.P., 1992 Response of intractable pain to continuous intrathecal morphine: a retrospective study. Pain 49, 21-25.

Goldberg, S., McGee, J., 2011. Pain as a global public health priority. BMC Public Health 11, 770.

Grady, K., Raphael, J., 2008. Spinal administration. In: Rice, A (Ed.), Textbook of Clinical Pain Management: Chronic Volume. Hodder Arnold, London, pp. 284-291.

Grider, J.S., Harned, M.E., Etscheidt, M.A., 2011. Patient selection and outcomes using a low-dose intrathecal opioid trialing method for chronic nonmalignant pain. Pain Physician 14, 343-351.

Guerrini, R., Calò, G., Rizzi, A., Bianchi, C., Lazarus, L., Salvadori, S., Temussi, P., Regoli, D., 1997. Address and message sequences for the nociceptin receptor: a structure-activity study of nociceptin-(1-13)-peptide amide. J. Med. Chem. 40, 1789-1793.

Hao, J.X., Wiesenfeld-Hallin, Z., Xu, X.J., 1997. Lack of cross-tolerance between the antinociceptive effect of intrathecal orphanin FQ and morphine in the rat Neurosci. Lett. 223, 49-52.

Hassenbusch, S.J., Paice, J.A., Patt, R.B., Bedder, M.D., Bell, G.K., 1997. Clinical realities and economic considerations: economics of intrathecal therapy. J. Pain Symptom. Manag. 14, S36-S48.

Hayek, S.M., Deer, T.R., Pope, J.E., Panchal, S.J., Patel, V.B., 2011. Intrathecal therapy for cancer and non-cancer pain. Pain Physician 14, 219-248.

Homberg, J.R., Mul, J.D., De Wit, E., Cuppen, E., 2009. Complete knockout of the nociceptin/orphanin FQ receptor in the rat does not induce compensatory changes in mu, delta and kappa opioid receptors. Neuroscience 163, 308-315. 
Hu, E., Calò, G., Guerrini, R., Ko, M.C., 2010. Long-lasting antinociceptive spinal effects in primates of the novel nociceptin/orphanin FQ receptor agonist UFP112. Pain 14, 107-113.

Huang, Y.N., Tsai, R.Y., Lin, S.L., Chien, C.C., Cherng, C.H., Wu, C.T., Yeh, C.C., Wong, C.S., 2012. Amitriptyline attenuates astrocyte activation and morphine tolerance in rats: role of the PSD-95/NR1/nNOS/PKC $\gamma$ signaling pathway. Behav. Brain Res. 229, 401-411.

Jhamandas, K.H., Sutak, M., Henderson, G., 1998. Antinociceptive and morphine modulatory actions of spinal orphanin FQ. Can. J. Physiol. Pharmacol. 76, 314-324.

Kieffer, B.L., Gavériaux-Ruff, C., 2002. Exploring the opioid system by gene knockout. Prog. Neurobiol. 66, 285-306.

Kieffer, B.L., 1999. Opioids: first lessons from knockout mice. Trends Pharmacol. Sci. $20,19-26$.

Kilkenny, C., Browne, W.J., Cuthill, I.C., Emerson, M., Altman, D.G., 2010. Improving bioscience research reporting: the ARRIVE guidelines for reporting animal research. J. Pharmacol. Pharmacother. 1, 94-99.

Ko, M.C., Naughton, N.N., 2009. Antinociceptive effects of nociceptin/orphanin FQ administered intrathecally in monkeys. J. Pain 10, 509-516.

Ko, M.C., Wei, H., Woods, J.H., Kennedy, R.T., 2006. Effects of intrathecally administered nociceptin/orphanin FQ in monkeys: behavioral and mass spectrometric studies. J. Pharmacol. Exp. Ther. 318, 1257-1264.

Koob, G.F., Bloom, F.E., 1988. Cellular and molecular mechanisms of drug dependence. Science 242, 715-723.

Kosson, D., Klinowiecka, A., Kosson, P., Bonney, I., Carr, D.B., Mayzner-Zawadzka, E. Lipkowski, A.W., 2008. Intrathecal antinociceptive interaction between the NMDA antagonist ketamine and the opioids, morphine and biphalin. Eur. J. Pain $12,611-616$

Krames, E.S., Gershow, J., Glassberg, A., Kenefick, T., Lyons, A., Taylor, P., Wilkie, D., 1985. Continuous infusion of spinally administered narcotics for the relief of pain due to malignant disorders. Cancer 56, 696-702.

Krames, E.S., Lanning, R.M., 1993. Intrathecal infusional analgesia for nonmalignant pain: analgesic efficacy of intrathecal opioid with or without bupivacaine. J. Pain Symptom. Manag. 8, 539-548.

Lambert, D.G., 2008. The nociceptin/orphanin FQ receptor: a target with broad therapeutic potential. Nat. Rev. Drug Discov. 7, 694-710.

Leighton, G.E., Rodriguez, R.E., Hill, R.G., Hughes, J., 1988. k-opioid agonist produce antinociception after i.v, and i.c.v, but not intrathecal administration in the rat. Br. J. Pharmacol. 93, 553-560.

Lin, A.P., Ko, M.C., 2013. The therapeutic potential of nociceptin/orphanin FQ receptor agonists as analgesics without abuse liability. ACS Chem. Neurosci. 4 214-224

Mamiya, T., Noda, Y., Ren, X., Nagai, T., Takeshima, H., Ukai, M., Nabeshima, T., 2001. Morphine tolerance and dependence in the nociceptin receptor knockout mice. J. Neural Transm. 108, 1349-1361.

Meunier, J.C., Mollereau, C., Toll, L., Suaudeau, C., Moisand, C., Alvinerie, P., Butour J.L., Guillemot, J.C., Ferrara, P., Monsarrat, B., 1995. Isolation and structure of the endogenous agonist of opioid receptor-like ORL1 receptor. Nature 377, $532-535$.

Morgan, M., 1989. The rational use of intrathecal and extradural opioids. Br. J Anaesth. 63, 165-188.

Nazzaro, C., Rizzi, A., Salvadori, S., Guerrini, R., Regoli, D., Zeilhofer, H.U., Calò, G., 2007. UFP-101 antagonizes the spinal antinociceptive effects of nociceptin orphanin FQ: behavioral and electrophysiological studies in mice. Peptides 28 663-669.

Nishi, M., Houtani, T., Noda, Y., Mamiya, T., Sato, K., Doi, T., Kuno, J., Takeshima, H., Nukada, T., Nabeshima, T., Yamashita, T., Noda, T., Sugimoto, T., 1997. Unrestrained nociceptive response and disregulation of hearing ability in mice lacking the nociceptin/orphaninFQ receptor. EMBO J. 16, 1858-1864.

Nordberg, G., Hedner, T., Mellstrand, T., Dahlström, B., 1984. Pharmacokinetic aspects of intrathecal morphine analgesia. Anesthesiology 60, 448-454.

Onofrio, B.M., Yaksh, T.L., 1990. Long-term pain relief produced by intratheca morphine infusion in 53 patients. J. Neurosurg. 72, 200-209.

Osborne, R., Joel, S., Trew, D., Slevin, M., 1990. Morphine and metabolite behavior after different routes of morphine administration: demonstration of the importance of the active metabolite morphine-6-glucuronide. Clin. Pharmacol. Ther. 47, 12-19.

Pasternak, G.W., Pan, Y.X., 2013. Mu opioids and their receptors: evolution of a concept. Pharmacol. Rev. 65, 1257-1317.
Pasternak, G.W., 1993. Pharmacological mechanisms of opioid analgesics. Clin. Neuropharmacol. 16, 1-18.

Reinscheid, R.K., Nothacker, H.P., Bourson, A., Ardati, A., Henningsen, R.A., Bunzow, J.R., Grandy, D.K., Langen, H., Monsma Jr., F.J., Civelli, O., 1995. Orphanin FQ: a neuropeptide that activates an opioidlike G protein-coupled receptor. Science 270, 792-794.

Reisine, T., Bell, G.I., 1993. Molecular biology of opioid receptors. Trends Neurosci. $16,506-510$.

Reisine, T., Pasternak, G., 1996. In: Hardman, J.G., Limbird, L.E. (Eds.), Goodman and Gilman's: The Pharmacological Basis of Therapeutics. McGraw-Hill, New York, pp. 521-555.

Rizzi, A., Spagnolo, B., Wainford, R.D., Fischetti, C., Guerrini, R., Marzola, G., Baldisserotto, A., Salvadori, S., Regoli, D., Kapusta, D.R., Calo, G., 2007. In vitro and in vivo studies on UFP-112, a novel potent and long lasting agonist selective for the nociceptin/orphanin FQ receptor. Peptides 28, 1240-1251.

Rizzi, A., Molinari, S., Marti, M., Marzola, G., Calo', G., 2011. Nociceptin/orphanin FQ receptor knockout rats: in vitro and in vivo studies. Neuropharmacology 60, $572-579$.

Rowbotham, M.C., 1995. Chronic pain: from theory to practical management. Neurology 45, 5-10.

Schroder, W., Lambert, D.G., Ko, M.C., Koch, T., 2014. Functional plasticity of the N/OFQ-NOP receptor system determines analgesic properties of NOP receptor agonists. Br. J. Pharmacol. , http://dx.doi.org/10.1111/bph.12744.

Smith, T.J., Swainey, C., Coyne, P.J., 2005. Pain management, including intrathecal pumps. Curr. Pain Headache Rep. 9, 243-248.

Toll, L., Caló, G., Cox, B.M., Chavkin, C., MacDonald, J., Civelli, O., Devi, L., Evans, C., Henderson, G., Höllt, V., Kieffer, B., Kitchen, I., Kreek, M., Liu-Chen, L., Meunier J., Portoghese, P., Shippenberg, T., Simon, Traynor, J., Ueda, H., Wong., Opioid receptors. Last modified on 07/04/2014. Accessed on 28/04/2014. IUPHAR database (IUPHAR-DB), 〈http://www.iuphar-db.org/DATABASE/FamilyMenuFor ward? familyId $=50\rangle$.

Ueda, H., Yamaguchi, T., Tokuyama, S., Inoue, M., Nishi, M., Takeshima, H., 1997. Partial loss of tolerance liability to morphine analgesia in mice lacking the nociceptin receptor gene. Neurosci. Lett. 237, 136-138.

Verhaak, P.F., Kerssens, J.J., Dekker, J., Sorbi, M.J., Bensing, J.M., 1998. Prevalence of chronic benign pain disorder among adults: a review of the literature. Pain 77, 231-239.

Vissers, K.C., Besse, K., Wagemans, M., Zuurmond, W., Giezeman, M.J., Lataster, A., Mekhail, N., Burton, A.W., Van Kleef, M., Huygen, F., 2011. Pain in patients with cancer. Pain Pract. 11, 453-475.

Waldhoer, M., Bartlett, S.E., Whistler, J.L., 2004. Opioid receptors. Annu. Rev, Biochem. 73, 953-990.

Wang, Y.Q., Zhu, C.B., Cao, X.D., Wu, G.C., 1999. Supraspinal hyperalgesia and spinal analgesia by [Phe1psi(CH2-NH)Gly2]nociceptin-(1-13)-NH2 in rat. Eur. J. Pharmacol. 376, R1-R3.

Weber, C., Reinecke, H., Simon, M., Lange, K., Sorgatz, H., 2012. Opioid guidelines: yesterday and today: current guideline recommendations for chronic nontumor pain. Anaesthesist 61, 625-629.

Wen, Z.H., Wu, G.J., Chang, Y.C., Wang, J.J., Wong, C.S., 2005. Dexamethasone modulates the development of morphine tolerance and expression of glutamate transporters in rats. Neuroscience 133, 807-817.

WHO, October 24, 2007. Access to Controlled Medications Programme: briefing note.

Williams, J.T., Ingram, S.L., Henderson, G., Chavkin, C., Von Zastrow, M., Schulz, S. Koch, T., Evans, C.J., Christie, M.J., 2013. Regulation of $\mu$-opioid receptors: desensitization, phosphorylation, internalization, and tolerance. Pharmacol. Rev. 65, 223-254.

Wojciech, L., 2011. Pain management in patients with cancer: focus on opioid analgesics. Curr. Pain Headache Rep. 15, 271-279.

Yaksh, T.L., Rudy, T.A., 1976. Chronic catheterization of the spinal subarachnoid space. Physiol. Behav. 17, 1031-1036.

Zadina, J.E., Harrison, L.M., Ge, L.J., Kastin, A.J., Chang, S.L., 1994. Differential regulation of mu and delta opiate receptors by morphine, selective agonists and antagonists and differentiating agents in SH-SY5Y human neuroblastoma cells. J. Pharmacol. Exp Ther. 270, 1086-1096.

Zeilhofer, H.U., Calò, G., 2003. Nociceptin/orphanin FQ and its receptor-potential targets for pain therapy? J. Pharmacol. Exp. Ther. 306, 423-429. 